\title{
Shrimp export from Bangladesh: Effect of war and trade liberalization
}

\author{
S. A. Sabur ${ }^{1}$, M. S. Palash ${ }^{1}$, M. A. Awal ${ }^{2}$ and K. T. Rahman ${ }^{3}$ \\ ${ }^{1}$ Department of Agribusiness and Marketing, Bangladesh Agricultural University, Mymensingh-2202, Bangladesh \\ ${ }^{2}$ On-Farm Research Division, BARI, Mymensingh, Bangladesh \\ ${ }^{3}$ Department of Agricultural Economics, BSMR Agricultural University, Gazipur, Bangladesh
}

\begin{abstract}
The study estimates the growth rates of frozen food, shrimp and total export, and instability of export earnings. The study evaluates the export marketing of frozen food; shrimp and fish by using time series aggregated data from the year of $1972-73$ to $2005-06$. The growth rates of frozen food were $44 \%, 11 \%$, and $10 \%$ during post-war period (197273 to 1982-83), pre-trade liberalization (1983-84 to 1992-93) and post-trade liberalization period (1993-94 to 2005-06) respectively. The export growth rate of shrimp was $43 \%$ in post-war period and $13 \%$ and $12 \%$ in the pre-trade liberalization and post-trade liberalization period respectively. The overall estimated shrimp export growth was $19 \%$. Total export earnings growth rate was much lower than shrimp growth rate in post-war period but it became higher in pre-trade liberalization and post-trade liberalization period. Export earnings including earnings from shrimp and frozen food was more stable in pre-trade liberalization period. Instability of export earnings from shrimp decreased markedly initially. It again increased in the recent past and the instability of shrimp export was lower than that of total export in all periods except post-trade liberalization period. The contribution of shrimp sector to total export earnings was $3.83 \%$ in 2005-06 and insignificant share of only $0.84 \%$ in the year $1972-73$. The present circumstances of this sector demands different institutional supports significantly from different angles to strengthen the position in the international market and ensuring more contribution to the economy.
\end{abstract}

Keywords: Growth rate, Instability, Shrimp export

\section{Introduction}

Agriculture plays a most crucial role in generating foreign exchange through increased export of agricultural products. Primary products including agricultural commodities are the major sources of foreign exchange for developing countries like Bangladesh. The trade experiences of developing countries reveal that there has been a steady decline in their share of the world agriculture export (McBean,1989). Bangladesh as an agrarian economy is no exception in this regard. In the country, fisheries received due recognition only recently because of their increasing role in nutrition, income, employment and foreign exchange earning. The main concern is that the frozen food and shrimp is viable to go on or not due to its adverse effects on soil, local agricultural fields, local atmosphere, sea level rise and conventional practices of the country. Economic development is often promoted by foreign trade with the help of exports. The export sector plays an imperative role in determining the rate and structural pattern of development of any country (Matin, 1991). Bangladesh with an agro-based economy is hardly trying to increase her export earnings for improving the balance of payment position in addition to its overall economic condition since eighties with a supportive export policy. But still the number of exportable items is not significant (Sarker et al.,1995). Shrimp, an agricultural product is recognized as a considerable one for its remarkable contribution in soaring the foreign exchange earnings and occupies the $4^{\text {th }}$ position among the export items. The export earnings from shrimp increased to Tk 28250.60 million in 2005-06 from Tk 22.65 million in $1972-73$ and its contribution to total export increased to $4.77 \%$ from $0.84 \%$ in the same period. Though the performance and earnings from exporting shrimp are not expected level that should have been attained. Hossain and Islam (1999) predicted that Bangladesh is able to increase foreign exchange earnings of Tk 50000 million annually by converting $25 \%$ of her existing shrimp cultivable land into semi-intensive farming. Keeping in view the aforesaid facts, the present study was undertaken with the objective to estimate the growth rate and instability of earning from shrimp export in post-war, pre- and post-trade liberalization periods of Bangladesh. 


\section{Materials and Methods}

The study was based on secondary data which were collected from various published and unpublished documents of government and non-government organizations. The growth rate and instability of shrimp exporting during post-war, pre- and post-trade liberalization periods were calculated using suitable models and indices. To achieve the stipulated objectives, the present study has been carried out based on shrimp export from Bangladesh pertaining the period 19972-73 to 2005-06, collected from the Export Promotion Bureau (EPB, 2006). This is the only government level institute responsible for collecting and storing necessary data required for future export planning and development of the country. Both tabular and functional techniques were applied for the analysis and interpretation of data.

Growth rates of frozen food export, shrimp export and total export were calculated for the following periods.

i) Post-war period ( $1972-73$ to 82-83)

ii) Pre-trade liberalization period ( $1983-84$ to 1992-93)

iii) Post-trade liberalization period (1993-94 to 2005-06)

iv) Overall period (1972-73 to 2005-06)

For estimating the growth rates, the following model was used.

$$
Y_{t}=Y_{0}(1+r)^{t} \text { or, } \operatorname{Ln} Y_{t}=\operatorname{Ln} Y_{0}+t \ln (1+r) \text { or, } \operatorname{Ln} Y_{t}=\beta_{1}+\beta_{2} t
$$

where, $\quad \beta_{1}=\operatorname{Ln} Y_{0}$

$$
\beta_{2}=\operatorname{Ln}(1+r)
$$

$\mathrm{Y}_{\mathrm{t}}=$ Total export /frozen food export/shrimp export earning in year $\mathrm{t}$

$Y_{0}=$ Initial total export /frozen food export/shrimp export price

$r=$ Compound growth rate $=\left(e^{b 2}-1\right)$ and also $t$ test statistic used for testing the significance of the estimates of the parameters.

\section{Measures of instability in export}

The measure of instability in time series data requires an explicit assumption of what constitute the acceptable and unacceptable components. A systematic component which can be predicted does not constitute instability and hence, it should be eliminated from data. The remaining unpredictable component represents the instability. Two methods, viz., moving average and trend fitting have been used in the literature to capture the predictable component. Here the preference is for three-year moving average since this form may more adequately keep in touch with influences on trend earnings, such as changing comparative advantage and policy changes. The estimate of the magnitude of instability in the time series data on exports has been attempted by computing the coefficient of variation (CV) and the percentage deviation from three-years moving average for each year.

$$
\begin{aligned}
& C V=\frac{\sigma}{\bar{X}_{t}} \times 100 \\
& \text { where, } \sigma=\text { Standard deviation }=\sqrt{\left(\frac{\sum X_{t}^{2}}{N}-\frac{\left(\sum X_{t}\right)^{2}}{N}\right)}, \bar{X}_{t}=\text { Period mean of } X_{t}
\end{aligned}
$$

$\mathrm{N}=$ number of years in the period

Percentage deviation $=\frac{X_{t}-X_{t}^{*}}{X_{t}^{*}} \times 100$

$\mathrm{X}_{\mathrm{t}}=$ observed value

$X_{t}^{*}=$ three years moving average 


\section{Results and Discussion}

\section{Export earnings from shrimp}

Bangladesh has achieved a remarkable progress in export earnings of frozen food, especially, shrimp. It occupies the $4^{\text {th }}$ position in the list of exportable items in terms of their total export earnings. The earnings shot up from Tk 23 million in 1972-73 to Tk 28250 million in 2005-06 (EPB, 2006). Period wise values of exports show that during 1993/94-2005/06 (Post-trade liberalization period) export earnings from shrimp increased 17 times as much as value of export during 1972-73 to 1982-83 (Post-war period) (Table 1). The contribution of shrimp to total export earnings although remained more or less same in post-trade liberalization period compared with post-war period. Overall, there existed large fluctuation during 197273 to 2005-06. The export share started increasing from $0.84 \%$ in 1972-73, reached the peak level of $11 \%$ in $1985-86$ and then declined to $3.83 \%$ in 2005-06 (Appendix Table 2 \& Fig. 3). That means although volume of shrimp export increased at faster rate than total volume of export in the initial period but could not cope with the expansion of total export in the later period. The earning share of total frozen food exported remained more or less same during the whole period.

Table 1. Export of shrimp in different periods of Bangladesh

\begin{tabular}{|l|c|c|c|c|}
\hline Particulars & $\begin{array}{c}\text { Post-war period } \\
(1972-73 \text { to } \\
1982-83)\end{array}$ & $\begin{array}{c}\text { Pre-trade } \\
\text { liberalization period } \\
(1983-84 \text { to 1992- } \\
93)\end{array}$ & $\begin{array}{c}\text { Post-trade } \\
\text { liberalization period } \\
\text { (1993-94 to 2005- } \\
\text { 06) }\end{array}$ & $\begin{array}{c}\text { Overall period } \\
(1972-73 \text { to } \\
2005-06)\end{array}$ \\
\hline Average total export (Million Tk) & 8069.52 & 45886.13 & 323804.53 & 139914.27 \\
\hline Average shrimp export (Million Tk) & 423.02 & 3634.54 & 15692.29 & 7205.84 \\
\hline $\begin{array}{l}\text { Average export of frozen food } \\
\text { (Million Tk) }\end{array}$ & 481.63 & 4127.73 & 17629.01 & 8110.36 \\
\hline Shrimp export as \% of total export & 5.24 & 7.92 & 4.85 & 5.15 \\
\hline $\begin{array}{l}\text { Shrimp export as \% of frozen food } \\
\text { export }\end{array}$ & 90.59 & 87.18 & 89.45 & 89.15 \\
\hline $\begin{array}{l}\text { Frozen food export as \% of total } \\
\text { export }\end{array}$ & 4.47 & 9.82 & 6.07 & 6.65 \\
\hline
\end{tabular}

Source: Author's own calculation data from EPB (2006).

Table 2. Growth rate of total export, shrimp export and frozen food export in different periods of Bangladesh

(Per cent)

\begin{tabular}{|l|c|c|c|c|}
\hline Variables & $\begin{array}{c}\text { Post-war period } \\
(1972-73 \text { to 1982- } \\
83)\end{array}$ & $\begin{array}{c}\text { Pre-trade } \\
\text { liberalization period } \\
(1983-84 \text { to 1992-93) }\end{array}$ & $\begin{array}{c}\text { Post-trade } \\
\text { liberalization period } \\
(1993-94 \text { to 2005-06) }\end{array}$ & $\begin{array}{c}\text { Overall period } \\
(1972-73 \text { to 2005- } \\
06)\end{array}$ \\
\hline \multirow{2}{*}{ Frozen food export } & $43.71^{\star \star}$ & $11.46^{\star \star}$ & $10.12^{\star \star}$ & $18.24^{\star \star}$ \\
& $(10.10)$ & $(6.72)$ & $(6.62)$ & $(12.19)$ \\
\hline \multirow{2}{*}{ Shrimp export } & $42.52^{\star \star}$ & $12.86^{\star \star}$ & $12.35^{\star \star}$ & $19.21^{\star \star}$ \\
& $(10.14)$ & $(8.83)$ & $(25.44)$ & $(16.40)$ \\
\hline \multirow{2}{*}{ Total export } & $18.64^{\star \star}$ & $16.82^{\star \star}$ & $16.37^{\star \star}$ & $16.88^{\star \star}$ \\
& $(14.52)$ & $(24.53)$ & $(58.11)$ & $(83.96)$ \\
\hline
\end{tabular}

Figures in the parentheses are $t$ values

** Denote significant at 1 percent level 


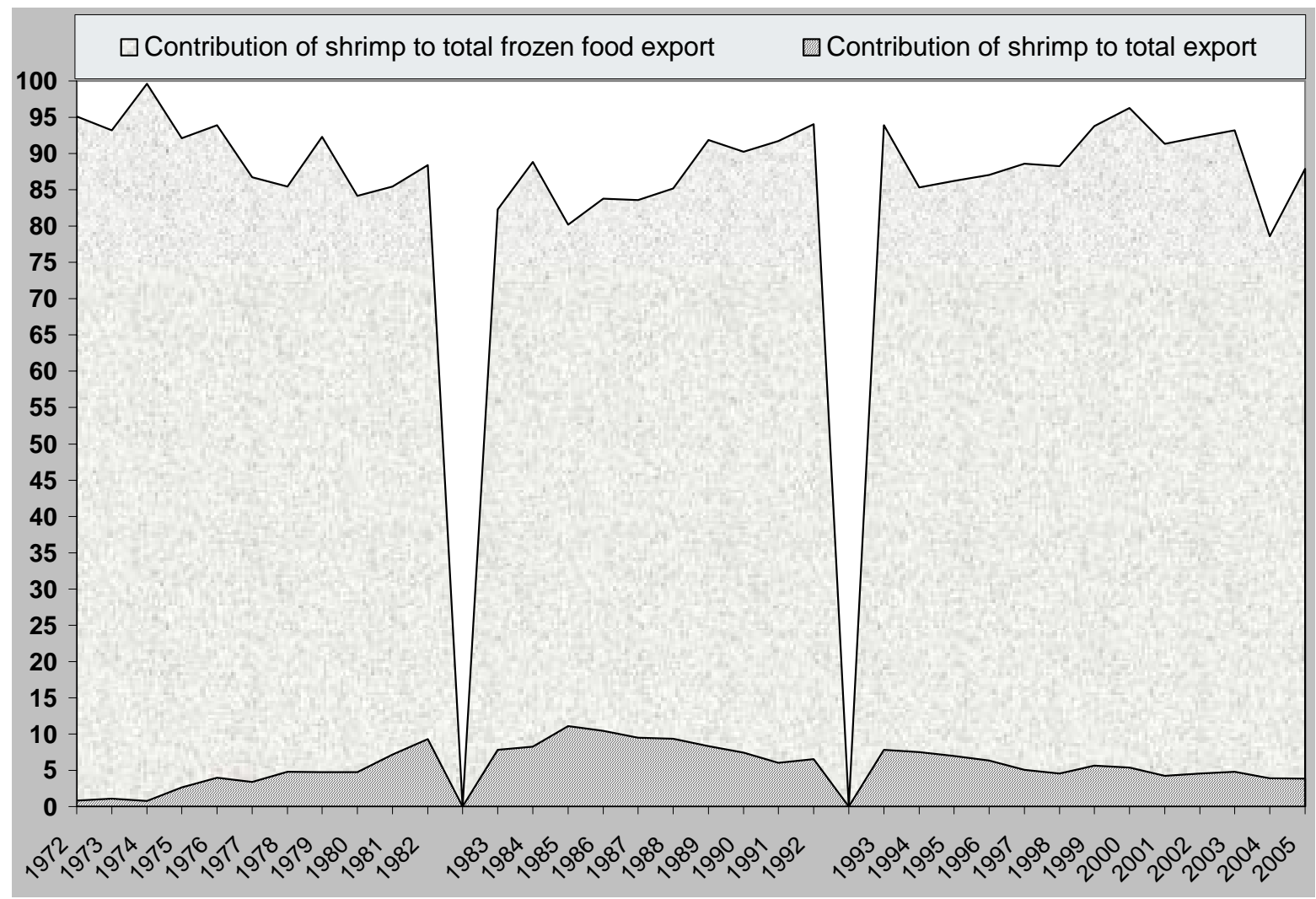

Fig. 1. Contribution of shrimp to total frozen food and total export earnings

\section{Growth rates of export earnings from shrimp in different periods}

Period-wise exponential growth rates of total export, frozen food export and shrimp export from Bangladesh were presented in Table 2. Export earnings from shrimp grew at $19 \%$ per annum during study period, which ranged from $43 \%$ in post-war period to $12 \%$ in post-trade liberalization period, revealing that growth rate has declined substantially in the post-trade liberalization period. Since $90 \%$ of frozen food export earning comes from shrimp, its growth rates are by and large same as the shrimp growth rates (Table 1). But it is not true for total export earning whose growth rate although was much lower than shrimp growth rate in post-war period it became higher in pre- and post-trade liberalization period. This indicates that government should examine the present export strategy in order to increase the export earnings share of frozen food, especially, shrimp in Bangladesh.

\section{Instability in export earnings from shrimp}

Table 3 shows the measure of instability for total export earning, earning from frozen food and shrimp that have calculated from percentage deviation of three-year moving averages. Since Bangladesh followed a socialist economy by nationalising all industries after its independence and besides due to political instability, there were critical shortages of factors of production in shrimp industries. External markets for shrimp had been disrupted because of the instability of supply. This sector began to grow rapidly in the 1990s, but was not appropriately attuned to the demands of sanitary facilities, technology adoption and training requirements that were called for in view of the increasingly rising stringent SPS-TBT (Sanitary and Phytosanitary - Tariff Barrier to Trade) compliance standards of the global market. These issues surfaced in late 1990s when shrimp export from Bangladesh faced sanctions from the shrimp importing countries (Center for Policy Dialogue, 2010). 
Export earnings including earnings from shrimp and frozen food was more stable in pre-trade liberalization period compared to other periods. Instability index of shrimp export was $18 \%$ in post-war period, which decreased to only $3 \%$ in pre-trade liberalization period and then again went up to $11 \%$ during post-trade liberalization period. The same type trend was found for total export and frozen food export but in recent past (post-trade liberalization period) shrimp export instability was greater than that of total export instability which was reverse to that prevailed in post-war period. The result revealed that instability of export earnings from shrimp decreased markedly initially but it increased in the recent past and the instability of shrimp export was lower than that of total export in all periods except post-trade liberalization period.

Table 3. Measurement of Instability in export earnings from Bangladesh in different periods

(Per cent)

\begin{tabular}{|l|c|c|c|c|}
\hline Particulars & $\begin{array}{c}\text { Post-war period } \\
(1972-73 \text { to 1982- } \\
83)\end{array}$ & $\begin{array}{c}\text { Pre-trade } \\
\text { liberalization period } \\
(1983-84 \text { to 1992- } \\
93)\end{array}$ & $\begin{array}{c}\text { Post-trade } \\
\text { liberalization period } \\
(1993-94 \text { to 2005- } \\
\text { 06) }\end{array}$ & $\begin{array}{c}\text { Overall period } \\
(1972-73 \text { to 2005- } \\
\text { 06) }\end{array}$ \\
\hline Total export & 35.18 & 3.45 & 8.66 & 15.12 \\
\hline Frozen food export & 17.64 & 4.12 & 22.34 & 15.40 \\
\hline Shrimp export & 18.09 & 3.29 & 10.55 & 10.63 \\
\hline
\end{tabular}

Source: Author's own calculation data from EPB (2006).

\section{Conclusion and Recommendation}

In Bangladesh the improvement and exploitation of the potential of frozen food export including shrimp has been slow. Although there is very profound demand for shrimp in overseas markets, Bangladesh couldn't make significant breakthrough in the factors related to shrimp export. Shrimp has been identified as an export focal point area in Bangladesh in new export policy. This focal point implies detection of export potential in the changing export market scenario. Recently Bangladesh shrimp producers have consolidated good contacts with German shrimp importers. As a result, German imports of Bangladeshi shrimp more than doubled to reach 5300 tonnes in the first nine months of 2009 . This country is now the number three exporter to Germany, behind Thailand and Viet Nam. India, formerly the top supplier to Germany, has lost its position (Shrimp Market Report, 2010). It is hoped that the government would extend all possible cooperation to shrimp producers/exporters to successfully address this challenge. In order to expand markets for Bangladesh's shrimp exports, producers, on their part, will have to ensure adherence to international standards, and high quality, particularly with regard to health, environment and labour standards.

\section{References}

Center for Policy Dialogue. 2010. State of the Bangladesh Economy in FY2009-10: From Stability to Accelerated Growth, Independent Review of Bangladesh's Development (IRBD), p.49.

EPB, 2006. Bangladesh Export Statistics, Export Promotion Bureau, Ministry of Commerce, Government of the Peoples Republic of Bangladesh, Dhaka.

Hossain, M.Z. and Islam, S.M.N. 1999. Export Marketing of Shrimp from Bangladesh: A study on Performance and Prospect. Bangladesh Journal of Development Review, 9(1\&2): 81-101.

MacBean, A. I. 1989. "Agricultural Exports of Developing Countries: Market Conditions and National Policies." In The Balance between Industry and Agriculture in Economic Development, ed. N. Islam, Macmillan Press Ltd., London, pp. 129-64. 
Matin, K.A. 1991. Export Performance of Bangladesh: Structure and Trends: 1972/1973 to 1990/91. Journal of Business Studies, Dhaka University, 13(2): 103 - 124.

Sarker, M.M.R., Waresul Karim, A.K.M. and Hossain, M.J. 1995. Export Marketing of Leather and Leather Products: A Study on Pattern, Problems and Prospects. Journal of the Institute of Cost and Management Accountants of Bangladesh, 22(3): 36-48.

Shrimp Market Report. 2010. www.vietfish.com/En/detail.php?id=9\&\&actitle=2470, Accessed date: June 10, 2010. 